\title{
HEMOGLOBIN LEVELS IN PREGNANT WOMEN LIVING IN COASTAL AND PLATEAU AREAS, KENDARI, INDONESIA
}

\author{
Anita Rosanty*, Reni Yunus \\ Department of Nursing, Polytechnic of Health of Kendari, Ministry of Health of the Republic of Indonesia
}

Accepted: 5 September 2017

*Correspondence:

Anita Rosanty, SST.,M.Kes

Department of Nursing, Polytechnic of Health of Kendari, Ministry of Health of the Republic of Indonesia

E-mail : unesa200852@yahoo.com

Copyright: (C) the author(s), YCAB publisher and Public Health of Indonesia. This is an open-access article distributed under the terms of the Creative Commons Attribution Non-Commercial License, which permits unrestricted non-commercial use, distribution, and reproduction in any medium, provided the original work is properly cited.

\begin{abstract}
Background: Insufficient hemoglobin levels are one of the most vulnerable health problems during pregnancy. Hemoglobin levels less than $11 \mathrm{~g} / \mathrm{dL}$ indicate anemia in pregnant women. However, it is assumed that there is a difference of hemoglobin levels between pregnant women in coastal and plateau areas.

Objective: To compare the hemoglobin levels in pregnant women who live in the coastal and plateau areas in the working area of the Community Health Center of Mata, Kendari.

Methods: This was an observational analytic research with cross sectional approach, conducted in MayJune 2014. There were 38 pregnant women using quota sampling, divided into 19 respondents in coastal areas and 19 respondents in plateau areas. Blood sampling was performed in each respondent, and categorized into mild, moderate, and severe anemia. Data were analyzed using chi-square test.

Results: The proportion of pregnant women with anemia in the working area of the Community Health Center of Mata was 94.74\%. Chi-square test showed p-value $0.307(>0.05)$.

Conclusion: There was no significant difference in hemoglobin levels in pregnant women in coastal and plateau areas in the working area of the Community Health Center of Kendari district.
\end{abstract}

Key words: Hemoglobin, pregnant women, coastal, plateau

\section{BACKGROUND}

One of the most vulnerable health problems in pregnant women is lack of hemoglobin levels. Hemoglobin levels less than $11 \mathrm{~g} / \mathrm{dL}$ indicates pregnant women suffer from anemia. This can increase the risk of getting low birth weight babies (LBW). In addition, if the pregnant mother is severely anemic, the risk of bleeding before and after labor is very likely to occur, even causing the death of the mother and baby. ${ }^{1-3}$

Anemia is one of the major problems that occur during pregnancy in developing countries, including Indonesia. Based on the 2007 Basic Health research, the prevalence of anemia in pregnancy was $14 \%$. Several studies in Indonesia have found anemia rates ranging from 20$80 \%{ }^{4,5}$ Hemoglobin level is a biochemical 
indicator to determine nutritional status. If there is a decrease in hemoglobin levels, then the red blood cell volume and hematocrit levels are below the normal value in a person's body. ${ }^{6}$

Anemia caused by lack of hemoglobin levels can be experienced by anyone, both male and female. However, women are so susceptible to anemia, because it has lower iron reserves than men, small body mass and blood loss during menstruation leads to women susceptible to anemia. Similarly in pregnant women, the need for iron increases from $1 \mathrm{mg} /$ day to $2.5 \mathrm{mg}$ / day in early pregnancy, and to $6.5 \mathrm{mg} /$ day in the 3rd trimester.

According to the World Health Organization (WHO), the prevalence rate of anemia in non-pregnant women is $30.2 \%$ while for pregnant women is $47.40 \%$. The incidence of anemia varies due to differences in socioeconomic conditions, lifestyle, and health behavior in different cultures. Anemia affects nearly half of all pregnant women in the world, $52 \%$ are in developing countries, while $23 \%$ in developed countries are commonly caused by malnutrition, malaria, worm infections, and schistomiasis. Human immunodeficiency virus (HIV) infections and hemoglobin abnormalities as additional factors. $^{7}$

Based on the 2001 national health survey data, the anemia rate in pregnant women was $40.1 \%$, indicated that anemia is quite high in Indonesia. When estimated in 2003-2010, the prevalence of anemia remains above $40 \%$, and then there will be maternal mortality as much as 18 thousand per year caused by bleeding after childbirth. This condition with an estimated $30-70 \%$ of mothers died due to severe anemia and by $20-40 \%$ of mothers died of indirect causes of anemia. ${ }^{8}$

Anemia is very dangerous for pregnant women. It has an effect that can harm the fetus and fetal death in the womb. The most common cause of anemia in pregnancy is iron deficiency (about $62.3 \%$ ). Anemia occurs from the empty reserves of body iron, so the supply of iron for erythropoiesis is reduced, which in turn the formation of hemoglobin is reduced. ${ }^{9}$

However, iron reserves in the body can be obtained from the consumption of foods containing iron. Simple amounts of iron can be obtained from meat, fish and vegetables. In addition to the lack of food reserves in the body, anemia can also be experienced due to the influence of the living environment.

Kendari city is an area with varied natural conditions. Terrain and hills with altitude on the northern part of Kendari Bay to Nipa-nipa Mountain are between 0300 meters above sea level. In the south, those range from 0-100 meters above sea level. While in the western part, it is a gently sloping plain with small surrounding hills. In addition, there are large coastal areas around the bay. ${ }^{10}$

The effect of hemoglobin on the environment is influenced by the percentage of oxygen in an area. Generally, oxygen levels reach $100 \%$ in coastal areas, and reach $25 \%$ in areas with altitude 9,000 meters above sea level. The higher the distance of an area from the sea surface, the lower the oxygen levels in the area.

Low oxygen levels will increase the production of erythropoietin hormone that induces hematopoietic stem cells into erythrocytes, whereas in areas with high oxygen levels, the body will produce erythrocytes normally. So the neighborhood can affect the hemoglobin level in a person's blood. ${ }^{11}$

\section{METHODS}

This was an observational analytic research with cross sectional approach, conducted in May-June 2014. The population of this 
study was pregnant women living in the area of community health center of Mata Area Kendari. There were 38 samples recruited using quota sampling, divided into 19 respondents in coastal areas and 19 respondents in plateau areas. The inclusion criteria of the samples were only pregnant women in trimester II and III. Blood sampling was performed in each respondent, and categorized into mild, moderate, and severe anemia. Data were analyzed using chi-square test.

\section{RESULTS}

Table 1 shows that pregnant women who were in trimester II were $63.16 \%$ and in trimester III were $36.84 \%$. While Table 2 shows that the majority of pregnant women in coastal areas had mild anemia (84.21\%) and $10.53 \%$ of respondents had moderate anemia. While in mountain areas, most of respondents had moderate $(42.11 \%)$ and mild anemia (52.63\%). Of all respondents, only 1 respondent had no anemia, both in coastal areas and plateau areas.

Table 1. Frequency distribution of respondents based on gestational age

\begin{tabular}{|c|c|c|}
\hline Gestational age & f & \% \\
\hline Trimester II & 24 & 63.16 \\
\hline Trimester III & 14 & 36.84 \\
\hline Total & 38 & 100 \\
\hline
\end{tabular}

Table 2. Frequency distribution of hemoglobin levels of pregnant mothers in coastal and plateau areas

\begin{tabular}{|l|c|c|}
\hline Hemoglobin levels (Hb) & f & \% \\
\hline In coastal areas & 2 & 10.53 \\
\hline Moderate Anemia & 16 & 84.21 \\
\hline Mild Anemia & 1 & 5.26 \\
\hline Normal & 19 & 100 \\
\hline Total & 8 & 42.11 \\
\hline In Plateau areas & 10 & 52.63 \\
\hline Moderate Anemia & 1 & 5.26 \\
\hline Mild Anemia & 19 & 100 \\
\hline Normal
\end{tabular}

Table 3. Difference of hemoglobin levels of pregnant mothers in coastal and plateau areas using chi-square test

\begin{tabular}{|c|c|c|c|c|c|c|c|c|c|}
\hline & \multirow{3}{*}{ Value } & \multirow{3}{*}{ df } & \multirow{3}{*}{$\begin{array}{c}\text { Asymp. } \\
\text { Sig. (2- } \\
\text { sided) }\end{array}$} & \multicolumn{3}{|c|}{ Monte Carlo Sig. (2-sided) } & \multicolumn{3}{|c|}{ Monte Carlo Sig. (1-sided) } \\
\hline & & & & \multirow[t]{2}{*}{ Sig. } & \multicolumn{2}{|c|}{$\begin{array}{l}\text { 95\% Confidence } \\
\text { Interval }\end{array}$} & \multicolumn{2}{|c|}{$\begin{array}{c}\text { 95\% Confidence } \\
\text { Interval } \\
\end{array}$} & \multirow[t]{2}{*}{ Sig. } \\
\hline & & & & & $\begin{array}{l}\text { Lower } \\
\text { Bound }\end{array}$ & $\begin{array}{l}\text { Upper } \\
\text { Bound }\end{array}$ & $\begin{array}{l}\text { Lower } \\
\text { Bound }\end{array}$ & $\begin{array}{l}\text { Upper } \\
\text { Bound }\end{array}$ & \\
\hline Pearson Chi-Square & $15.000^{\mathrm{a}}$ & 13 & .307 & $.158^{\mathrm{b}}$ & .042 & .274 & & & \\
\hline Likelihood Ratio & 19.721 & 13 & .102 & $.184^{\mathrm{b}}$ & .061 & .307 & & & \\
\hline Fisher's Exact Test & 14.128 & & & $.211^{\mathrm{b}}$ & .081 & .340 & & & \\
\hline $\begin{array}{l}\text { Linear-by-Linear } \\
\text { Association }\end{array}$ & $.382^{\mathrm{c}}$ & 1 & .537 & $.579^{\mathrm{b}}$ & .422 & .736 & .168 & .464 & $.316^{\mathrm{b}}$ \\
\hline $\mathrm{N}$ of Valid Cases & 38 & & & & & & & & \\
\hline
\end{tabular}

Table 3 shows that the value of $\mathrm{x} 2$ count (15.000) was lower than $\mathrm{x} 2$ table $(22,362)$, with $p$ value $(0.307)(>0.050)$. it can be concluded that Ho was accepted, which indicated that there was no significant difference of hemoglobin levels in pregnant women who live in the coastal areas and plateau areas in Kendari district. 


\section{DISCUSSION}

The purpose of this study was to determine differences in hemoglobin levels of pregnant women who live in coastal and plateau areas. Findings in this study revealed that there was no significant difference in hemoglobin levels for pregnant mothers in coastal and plateau areas. This is in contrast with previous study revealed that there is a significant difference in hemoglobin level between pregnant women living in coastal areas and in plateau areas. ${ }^{12}$

The low level of hemoglobin in pregnant mothers in coastal areas is likely due to high oxygen pressure resulting in normal erythrocyte formation. But in pregnant women, normal formation of erythrocytes is not necessarily good. It is because at the time of pregnancy, erythrocyte production is still lower than the formation of plasma, thus causing the blood becomes more dilute.

Similarly, pregnant mothers in plateau areas had low level of hemoglobin, which might be because of the plateau areas in Kendari were not high enough. So the formation of oxygen does not increase, but normal. In addition, currently in these areas, pregnant women tend to choose to use motor vehicles, instead of walking. Thus, the capacity of the lungs is similar to that of pregnant women in the coastal areas. By walking, oxygen into the lungs will increase and cause an increase in hemoglobin levels. This is suspected to be the underlying cause of the absence of significant differences in pregnant women's hemoglobin levels living in coastal areas and in plateau areas in Kendari district, but there was a difference in maternal anemia status from both areas (see Table 2).

However, besides a geographical factor as revelaed in this study, there are many other factors identified in literatures affecting hemoglobin levels, such as the compliance in consuming iron tablets, nutritional status, maternal education, pregnant women's work and parity. Astrini $^{13}$ revealed that pregnant women who consumed iron tablets obediently were still susceptible to mild anemia, while pregnant women who did not consume iron tablets tend to have moderate anemia.

Pregnant women in both areas in this study admitted that tend to be lazy to consume iron tablets because they feel nausea, discomfort in the pit of the stomach and vomiting. But, because of the high rate of anemia in both areas, especially in the area of the Community health Center of Eye Health Center, it is recommended to pregnant women to do prevention as early as possible by consuming blood booster tablets. To reduce nausea, it is advisable not to consume with tea. And to facilitate the absorption of iron, it is advisable to consume together with vitamin $\mathrm{C}$, in the form of tablets or fruits that contain vitamin $\mathrm{C}$.

\section{CONCLUSION}

Based on the results of this study, there was no significant difference in hemoglobin levels in pregnant women in coastal and plateau areas in the working area of the Community Health Center of Kendari district.

\section{REFERENCES}

1. Cunningham F, Leveno K, Bloom $\mathrm{S}$, Spong CY, Dashe J. Williams Obstetrics, 24e: McGraw-Hill; 2014.

2. Damanik SM. Klasifikasi Bayi Menurut Berat Lahir dan Masa Gestasi. Buku Ajar Neonatologi. Edisi I. Jakarta: Badan Penerbit IDAI. 2008:11-30.

3. MOH. Profil Kesehatan Indonesia 2014: Menteri Kesehatan Republik Indonesia, Jakarta;2014. 
4. Departemen Kesehatan RI. Laporan Nasional Riskesdas 2007. Jakarta: Badan Penelitian dan Pengembangan Kesehatan Departemen Kesehatan Republik Indonesia. 2008.

5. Kusumah UW. Kadar Haemoglobin Ibu Hamil Trimester II-III Dan Faktor-Faktor Yang Mempengaruhinya Di RSUP $H$. Adam Malik Medan Tahun 20092009.

6. Bradford R, Behl A, Culbet $\mathrm{M}$. Live blood analysis. American Biologics. 1987:r66.

7. Fuady M. Hubungan Pengetahuan Ibu Hamil tentang Anemia Defisiensi Besi terhadap Kepatuhan Mengkonsumsi Tablet Zat Besi. ejurnal Fakultas Kedokteran USU. 2013;1(1).

8. Surkesnas T. Survei Kesehatan Nasional 2001. Laporan SKRT. 2001;200(1).

9. Lops VR, Hunter LP, Dixon LR. Anemia in pregnancy. American family physician. 1995;51(5):11891197.
10. Kendari DK. Profil Dinas Kesehatan Kota Kendari Tahun 2015: Kendari; 2012.

11. Proverawati A. Anemia dan Anemia kehamilan. Yogyakarta: Nuha Medika. 2011:136-137.

12. Sinatra MT. Perbedaan prevalensi anemia defisiensi besi pada perempuan hamil di daerah pantai dan pegunungan di wilayah Semarang. Indonesian Journal of Obstetrics and Gynecology (INAJOG). 2016;33(2).

13. Astrini Y. Hubungan Konsumsi Tablet Besi Dengan Status Anemia Ibu Hamil Di Puskesmas LepoLepo. Kendari2013.

Cite this article as: Rosanty $\mathrm{A}$, Yunus R. Hemoglobin Levels in Pregnant Women Living in Coastal And Plateau Areas, Kendari, Indonesia. Public Health of Indonesia 2017;3(3):102-106 